\title{
Prevalence of Birth Asphyxia and Associated Factors among Neonates Delivered in Dilchora Referral Hospital, in Dire Dawa, Eastern Ethiopia
}

Neil Abdurashid Ibrahim ${ }^{1 *}$, Ahmed Muhye ${ }^{2}$ and Selah Abdulie ${ }^{3}$

${ }^{1}$ Department of Midwifery, College of Medicine and Health Science, Dire Dawa University, Dire Dawa, Ethiopia

${ }^{2}$ Department of Anesthesia, College of Medicine and Health Science, Dire Dawa University, Dire Dawa, Ethiopia

${ }^{3}$ General Practice, Hiwot Fana Specialized University Hospital, Harar, Ethiopia

*Corresponding author: Ibrahim NA, Department of Midwifery, College of Medicine and Health Science, Dire Dawa University, Dire Dawa, Ethiopia, Tel: +251911833310; E-mail: firdowsayuzarsif@gmail.com

Received date: November 06, 2017; Accepted date: December 11, 2017; Published date: December 22, 2017

Copyright: @2017 Ibrahim NA. This is an open-access article distributed under the terms of the Creative Commons Attribution License, which permits unrestricted use, distribution, and reproduction in any medium, provided the original author and source are credited.

\begin{abstract}
Introduction: The greatest gap in new-born care is often during the critical first week of life when most neonatal and maternal deaths often occur at home and without any contact with the formal health sector. Some unacceptable practices such as unskilled attendants during delivery, unhygienic delivery practices, taboos and superstitions associated with caring for the new-born greatly affect new-born survival in Ethiopia.
\end{abstract}

The aim of this study is to identify the prevalence and associated factors of birth asphyxia among babies born in Dilchora referral hospital.

Methods and materials: Hospital based retrospective study design was used among babies born in Dilchora referral hospital of three years of study period from $1^{\text {st }}$ July 2014 to $30^{\text {th }}$ June 2017 and admitted to NICU with APGAR score $<7$ at $5^{\text {th }} \mathrm{min}$. Data was collected by two data collectors by reviewing NICU registration book.

Result: Of 9738 babies born in the study period, 302 (3.1\%) had birth asphyxia from our records; but only 246 $(81.5 \%)$ case files with complete documentations were retrieved, giving a prevalence of $2.5 \%$ or $25 / 1000$ live birth. Age ranges between 15 to 25 (AOR, 0.04; Cl 0.03-0.07) and (AOR, 0.02; Cl 0.050-0.091) Who were illiterate (AOR, 0.08 ; $\mathrm{Cl} 0.035-0.049$ ) and who were primary educational level (AOR, 0.04; $\mathrm{Cl} 0.023-0.043$ ) Born with vacuum delivery AOR, 0.042; $\mathrm{Cl} 0.082-0.043$ ) and Forceps delivery (AOR, 0.05; $\mathrm{Cl} 0.06-0.09$ ) duration of labour <18 $\mathrm{h}$ (AOR, 0.017; Cl 0.012-0.9) were important determinant factors for birth asphyxia.

Conclusion and recommendation: Prevalence of birth asphyxia was almost close to the national prevalence 29/1000 live births. APGAR score at $5^{\text {th }}$ min were $204(82.9 \%)$ 4-6 and $42(17.1 \%)$ 0-3 scores. Two hundred nineteen $(89 \%)$ of babies were discharged; while $27(11 \%)$ died. So higher official of regional health bureau and hospital administrators as well NGOs should have to act collaboratively in order to improve poor birth outcome.

Keywords: Birth; Neonatal asphyxia

Abbreviations AAP: American Academy of Paediatrics; ACOG: American College of Obstetricians and Gynaecologists; ANC: Ante Natal Care; APGAR: Appearance, Pulse Rate, Grimace, Activity, Respiration Rate; BA: Birth Asphyxia; DRH: Dilchora Referral Hospital; EDHS: Ethiopian Demographic Health Survey; FMOH: Federal Ministry Of Health; GA: Gestational Age; NICU: Neonatal Intensive Care Unit; WHO: World Health Organization; NMR: Neonatal Mortality Rate; IMR: Infant Mortality Rate; CMR: Child Mortality Rate

\section{Introduction}

World Health Organization defined birth asphyxia as "the failure to initiate and sustain breathing at birth [1-3]. The exact definition of birth asphyxia is given by the ACOG, AAP includes existence of 3 factors: Metabolic or mixed academia $(\mathrm{pH}<7)$ which is determined by umbilical cord arterial blood samples; APGAR score of $<3$ for longer than $5 \mathrm{~min}$; neurological manifestations; and multisystem organ dysfunction [4-6] this definition is designed for use in hospital-based settings which requires evaluation.

Worldwide Midwives uses APGAR score for describing the wellbeing of new-borns at birth [7]. Because it is a clinical indicator commonly used to describe the new-born's physical condition at birth. In many cases, the timing of asphyxia cannot be established with certainty [8] that is why the severity of asphyxia is widely assessed by the Apgar score, at 1 and 5 min after birth [9]. Commonly the first 1 min after birth which is the "golden minute" the baby should be breathing well [10]. The ACOG stated that a low APGAR score beyond $5 \mathrm{~min}$ is a suggestive criterion for an estimate of the severity of asphyxia $[9,11]$.

The birth of a healthy new-born is one of the finest gifts of nature. The birth process takes only few hours but it is the most hazardous period of life since it is associated with the largest number of deaths as compared to any other phase of life [12]. If new-born is unable to breathe spontaneously at birth it results birth asphyxia [10] and causes a damaging condition of impaired blood gas exchange and if it persists leading to progressive hypoxemia, hypercapnia with significant 
metabolic acidosis and tissue oxygen debt, which can cause serious multi organ failure and poor prognosis and high mortality stillbirth or lifelong disability in the surviving infant [13-19] commonly with a very high incidence of $25 \%$ irreversible neurologic damage [8,20-25] and 1.15 million develop clinical encephalopathy [26-28] such as cerebral palsy, mental retardation and epilepsy leading to detrimental long term consequences for both child and family $[29,30]$. Cognitive and behavioural difficulties $[18,19]$ which leads to memory and attention deficit hyperactivity disorder (ADHD), autism and schizophrenia $[31,32]$.

Globally birth asphyxia continues to present a major clinical problem $[25,33,34]$ and one of the common and leading causes of perinatal and neonatal mortality and morbidity especially in developing countries $[8,10,25,33,35-37]$. Four million babies are born with asphyxia each year. According to statistics by WHO, in developing countries $3 \%$ of infants (3.6 million babies) suffer from moderate to severe asphyxia, of whom $23 \%(840,000)$ die which equates to nearly 1 million neonatal deaths per year $[1,38]$ and in a countries with high neonatal mortality rates the death rate is 8 times that of countries with low NMRs and almost the same number suffer from the associated consequences $[39,25]$.

The prevalence of birth asphyxia is increasing; in 1990s the incidence of asphyxia was reported as 5.4/1000 live births [40] while in the 2006 the ACOG reported 25-73/1000 live births [14] in developed countries an incidence of 1-6/1,000 live births, and birth asphyxia (23\%) represents the third most common cause of neonatal death [41] and 5-10/1000 live births in developing countries with $24-29 \%$ of neonatal deaths $[42,43]$ upto $99 \%$ of these deaths occurred in LMIC [22].

Africa accounts for $11 \%$ of the world's population but more than $25 \%$ of the world's new-born deaths. Of every 4 children who die in Africa, one is a newborn [44]. Due to this neonatal deaths have remained stagnant globally $[25,45,46]$ In Ethiopia NMR accounts $29 / 1000$ live birth. A large proportion of this death occurs during the first $48 \mathrm{~h}$ after delivery and still declined little [47].

Babies born in sub-Saharan Africa have a very high risk of birth asphyxia because 280,000 deaths occur due to birth asphyxia during first day of life $[25,44,48,49]$. Usually hospital data shows a very high percentage of deaths due to asphyxia since complicated births are more likely to come to hospital. Birth asphyxia is one among top three causes of new-born deaths next to infections and complications of preterm birth which together account for $88 \%$ of newborn deaths in Africa of which birth asphyxia accounts 24\% [44] and 22\% developed complication of asphyxia [50] and it is still the fifth largest cause of under-five mortality [51]. In Ethiopia BA accounting 23\% of 29/1000 live birth neonates mortality [38].

A series of various maternal, obstetrical, and foetal factors cause hypoxia in the foetus and asphyxia in the new-born. Therefore, the risk factors are associated with decreased blood flow and oxygenation to the tissues [52,53]. So birth asphyxia can be caused by events that have their roots in $50 \%$ of cases primarily antepartum in origin, $40 \%$ cases intra-partum and remaining $10 \%$ of cases are postpartum periods or combinations thereof $[3,33,41,54]$. Lack of referrals and inadequate and inappropriate resuscitation measures and lack of modern obstetric care, and lack of therapeutic hypothermia lack of PICU nurses; lack of intensive care technologists; lack of basic paediatric critical care training for nurses to provide effective paediatric advanced life support; inadequate resuscitation efforts; paediatric nurses' inabilities to recognize critically ill neonates; lack of modern or advanced equipment; and lack of transport services to facilitate movement of babies from peripheral hospitals to neonatal units will contribute to increased risks of neonatal asphyxia [33,55,56].

In most African countries including Ethiopia and in the study area there is lack of availability of prevalence of birth asphyxia and related study literatures. So the aim of this study is to fulfil this gap by assessing the prevalence of neonatal asphyxia and its associated factors among babies born in DRH.

\section{Methods and Materials}

The study was conducted in DRF which was established in 1952 in Dire-dawa city, $515 \mathrm{~km}$ east of capital city of Addis Ababa. It is the only referral hospital in the city administration that provided service approximately 11,229 inpatient and 118,886 outpatient attendees in $2016 / 2017$ coming from catchment population of 500,000. The hospital has different departments those renders comprehensive health services by care providers from different department and professional levels. The maternity unit provides service for more than 3000 clients a year with a total of 28 beds, three labour couch, 18 midwives, 1 general practitioner, 3 obstetrics and gynaecologist. Two caesarean section tables with 7 nurses, 1 scrub nurse, 2 anaesthetists. Neonatal ICU has 12 beds, 3 incubators, 2 radiant warmers and staffs of 10 BSc nurses, 3 interns, and 2 senior paediatricians. The NICU offers diagnostic and treatment for approximately 1000 babies per year.

\section{Study design and period}

Facility based retrospective study design was conducted from July1/2014-June 30/2017 (N=9738).

\section{Source population}

All delivery records (babies delivered) used at Dilchora referral hospital from July1/2014-June.

\section{Study population}

All 246 delivery records with birth asphyxia.

\section{Sampling technique and sample size}

All 246 cases files with birth asphyxia were taken purposively since our source population and study population is the same.

\section{Study subjects}

Babies who were admitted into NICU with APGAR score $<7$ at $5^{\text {th }}$ $\min$.

APGAR score was one of the criteria used to define birth asphyxia in this study, due to unavailability of blood gas analysis in babies delivered in the hospital. It is moderate asphyxia if the 5 min APGAR score is $4-6$, or required stimulation and oxygen administration before a cry. Severe asphyxia is when the score is $0-3$.

Diagnostic criteria of birth asphyxia:

Gestational age greater than equal to 28 weeks.

Birth weight $>1000 \mathrm{~g}$. 
Citation: Ibrahim NA, Muhye A, Abdulie S (2017) Prevalence of Birth Asphyxia and Associated Factors among Neonates Delivered in Dilchora Referral Hospital, in Dire Dawa, Eastern Ethiopia. Clinics Mother Child Health 14: 279. doi:10.4172/2090-7214.1000279

Page 3 of 7

Birth asphyxia: when babies are unable to breathe at birth or after birth by its own effort with APGAR score at $5^{\text {th }} \min <7$.

Exclusion criteria: Data with incomplete documentation (which has no maternal or foetal measurement parameters properly).

Born in other health facility and admitted to NICU.

Presence of major congenital malformation (hydrops, NTD).

Maternal analgesia, prematurity and infection, (may cause depression of the Apgar score).

Metabolic disorders.

The records for patients with birth asphyxia were perused using a checklist which was adopted after reviewing different literatures which addresses the following aspects: socio-demographic data, maternal information (ANC visits, mode of delivery); neonatal information (gender birth weight and APGAR score).

\section{Study protocol}

APGAR scoring consists of five physical sign: colour, heart rate, reflex irritability, muscle tone, respiratory effort. In our study Birth asphyxia is define when babies are unable to breathe at $5^{\text {th }}$ min after birth and APGAR score $<7$ at $5^{\text {th }} \mathrm{min}$.

ANC follow up at least once in her last pregnancy, GA is based on LMP and fundal height measurement, Educational status which contains Illiterate (unable to read and write). Primary education, secondary education, higher education (college/university), previous delivery history like no abnormal labour and delivery history (normal labour).

\section{Data collection method}

The data was collected through record review using pre-tested structured check lists. Prior to analysis, data was cleaned, coded, checked for normality, completeness, and entered into SPSS version 16.0. Frequency, descriptive statistics was computed to determine the prevalence of birth asphyxia and socio-demographic as well obstetrics history. Bivariate and multiple logistic regression analysis were carried out to see significance of the associated factors at $p$ value $<0.05$ at $95 \%$ CI.

\section{Result}

During the study period, a total of 9738 babies born and of which 302 (3.1\%) babies were admitted to NICU with birth asphyxia as documented in our record book with APGAR score of $<7$ at $5^{\text {th }}$ min. However, we were able to retrieve case files of 246 (81.5\%) babies records had complete data, which gave us a prevalence of $2.5 \%$.

\section{Socio-demographic characteristics of the study participants}

Of $246(81.6 \%)$ babies the prevalence of birth asphyxia accounts 25/1000 live birth. The majority of mothers of asphyxiated babies 92 (37\%) were age 21-25 years old (mean 2.54, SD 1.09). Maternal education statuses were 136 (55.3\%) illiterate. Regarding the residence of mothers 135 (56.1\%) were living in rural and 117 (47.6\%) Muslim by religion and $164(66.7 \%)$ were house wife (Table 1$)$.

\section{Obstetrics history of mothers}

One hundred seventy seven (72\%) had spontaneous vaginal delivered and 8 (3.9\%) were delivered by C/S. 206 (83.6\%) mothers gave birth between 6 to $18 \mathrm{~h}$ from the onset of labour and the remaining 40 (16\%) delivered after $18 \mathrm{~h}$.

Regarding membrane about 129 (52.4\%) had rupture of member intra partum while the remaining $117(47.6 \%)$ developed premature rapture of membrane. Regarding maternal antenatal follow-up 209 (85\%) had follow-up at least once prior to delivery and about $24(9.8 \%)$ of had hypertension history. Based on the previous obstetric history of mothers 12 (4.9\%) had premature birth, 12 (4.9\%) neonatal death, 11 (4.5\%) intra uterine death, 20 (8.1\%) abortion and 191 (77.6\%) had normal labour and delivery history (Table 2).

\begin{tabular}{|c|c|c|}
\hline Characteristics & $n=246$ & $\%$ \\
\hline \multicolumn{3}{|l|}{ Age } \\
\hline $15-20$ years & 40 & 16.3 \\
\hline $21-25$ years & 92 & 37.4 \\
\hline $26-30$ years & 69 & 28 \\
\hline $31-35$ years & 39 & 12.2 \\
\hline $36-40$ years & 15 & 6.1 \\
\hline \multicolumn{3}{|c|}{ Educational status } \\
\hline Illiterate & 136 & 55.3 \\
\hline Primary & 64 & 26 \\
\hline Secondary & 30 & 12.2 \\
\hline Higher educ. & 16 & 6.5 \\
\hline \multicolumn{3}{|l|}{ Residence } \\
\hline Rural & 138 & 56.1 \\
\hline Urban & 108 & 43.9 \\
\hline \multicolumn{3}{|l|}{ Religion } \\
\hline Muslim & 117 & 47.6 \\
\hline Orthodox & 91 & 36.9 \\
\hline Protestant & 21 & 8.5 \\
\hline Catholic & 13 & 5.3 \\
\hline Others & 4 & 1.7 \\
\hline \multicolumn{3}{|c|}{ Occupation status } \\
\hline House wife & 164 & 66.7 \\
\hline Private & 40 & 16.3 \\
\hline Government & 18 & 7.3 \\
\hline Other & 24 & 9.8 \\
\hline
\end{tabular}

Table 1: Socio-demographic characteristics of mother at Diredawa, Ethiopia $2017(\mathrm{n}=246)$. 
Citation: Ibrahim NA, Muhye A, Abdulie S (2017) Prevalence of Birth Asphyxia and Associated Factors among Neonates Delivered in Dilchora Referral Hospital, in Dire Dawa, Eastern Ethiopia. Clinics Mother Child Health 14: 279. doi:10.4172/2090-7214.1000279

Page 4 of 7

\section{Clinical picture of asphyxiated baby}

APGAR score of the babies was $204(82.9 \%)$ 4-6 had mild birth asphyxia while the remaining 42 (17.1\%) $0-3$ had severe birth asphyxia at fifth minutes. Two hundred nineteen $(89 \%)$ of new-borns were resuscitated and discharged; while 27 new-borns died, giving a case fatality rate of $11 \%$. Majority of them $200(81.3 \%)$ were weighed between 2.5 to $3.9 \mathrm{~kg} .153(62.2 \%)$ of babies born were male (Table 3 ).

\begin{tabular}{|c|c|c|}
\hline Characteristics & $n=246$ & Present \\
\hline \multicolumn{3}{|l|}{ Mode of delivery } \\
\hline SVD & 177 & 72 \\
\hline Vacuum delivery & 19 & 7.7 \\
\hline Forceps delivery & 8 & 3.9 \\
\hline $\mathrm{C} / \mathrm{S}$ & 42 & 17.1 \\
\hline \multicolumn{3}{|l|}{ Labour time } \\
\hline$<18 \mathrm{~h}$ & 206 & 83.7 \\
\hline$\geq 18 \mathrm{~h}$ & 40 & 16.3 \\
\hline
\end{tabular}

\section{Rupture of membrane}

\begin{tabular}{|l|l|l|}
\hline Premature rapture & 117 & 47.6 \\
\hline Intra-partum rupture & 129 & 52.4 \\
\hline Maternal illness & 24 & 9.8 \\
\hline Hypertension & 6 & 2.4 \\
\hline Diabetes mellitus & 206 & 83.7 \\
\hline No medical illness & 10 & 4.1 \\
\hline Other & &
\end{tabular}

\section{Previous delivery history}

\begin{tabular}{|l|l|l|}
\hline Premature birth & 12 & 4.9 \\
\hline Neonatal death & 12 & 4.9 \\
\hline Intra uterine death & 11 & 4.5 \\
\hline Abortion & 20 & 8.1 \\
\hline No bad labour history & 191 & 77.6 \\
\hline
\end{tabular}

\section{ANC follow up}

\begin{tabular}{|l|l|l|}
\hline No & 37 & 15 \\
\hline Yes & 209 & 85 \\
\hline Gestational age & \multicolumn{2}{|l|}{} \\
\hline 37 weeks above & 210 & 85.4 \\
\hline 32-37 weeks & 33 & 13.4 \\
\hline $28-32$ weeks & 3 & 1.2 \\
\hline
\end{tabular}

Table 2: Obstetrics history of mothers at Dilchora referral hospital Diredawa, Ethiopia 2017.

\section{Discussion}

In our study, the prevalence of birth asphyxia was 2.5 live births in past 3 years at DRH. This finding is lower than study done in Gusau Nigeria (21.1\%) [51]. In Dar es Salaam Tanzania (21.1\%) [33] Malawi (6.1\%) [57]. In Cameroon (8.1\%) but higher than study done in Iran (1\%) [58]. This fluctuating incidence could be explained by the difference in the methodology used in different studies.

In our study $27(11 \%)$ Neonates were died due to birth asphyxia after resuscitation which is similar with study done in six sub-Saharan Africa [59] but lower than study done in Tigray 31\% [60] and in Jimma 23.2\% [61] of Ethiopia and in Tanzania dar es salaam 62.5\% [33] And in Nagaur, India (39\%) [62] and 26\% in Iran [57]. But higher than study done in IRAN (3.1\%) [63]. In Gusau Nigeria (5.4\%) in Cameroon $6.7 \%[63,64]$.

\begin{tabular}{|c|c|c|}
\hline Characteristics & $(n=246)$ & $\%$ \\
\hline \multicolumn{3}{|l|}{ APGAR score } \\
\hline $0-3$ scores & 42 & 17.1 \\
\hline 4-6 scores & 204 & 82.9 \\
\hline \multicolumn{3}{|c|}{ Baby cried after resuscitation } \\
\hline No & 27 & 11 \\
\hline Yes & 219 & 89 \\
\hline \multicolumn{3}{|c|}{ Birth weight of the newborn } \\
\hline 1000 to $1499 \mathrm{~g}$ & 10 & 4.1 \\
\hline 1500 to $2499 \mathrm{~g}$ & 34 & 13.8 \\
\hline 2500 to $3999 \mathrm{~g}$ & 200 & 81.3 \\
\hline$\geq 4000 \mathrm{~g}$ & 2 & 8 \\
\hline \multicolumn{3}{|l|}{ Sex of the baby } \\
\hline Male & 153 & 62.2 \\
\hline Female & 93 & 37.8 \\
\hline
\end{tabular}

Table 3: Clinical picture of asphyxiated baby born in Dilchora referral hospital, Dire-dawa, Ethiopia 2017.

The possible explanations for this difference might be due to variation in study setup, health care providers believes, awareness of health, guideline on child birth and delivery, training, availability of modern tools $[65,66]$.

In our study there was statistically significance association found between birth asphyxia and age of mother. Maternal age group 15-20 years were four times $[\mathrm{AOR}=0.04,95 \% \mathrm{CI}(0.03-0.07)]$ and age between 21-25 years old were two times AOR=0.02, 95\% CI (0.050-0.091) to develop birth asphyxia when compared to age $26-30$ years old.

This finding is consistent with study done in at a national hospital in Dar es Salaam, Tanzania. $27.5 \%$ of the birth asphyxiated babies' mother's age were younger than 24 years [33] and Montreal [3] Karachi, Pakistan [67] but inconsistent with studies done in Rural in Dhaka Medical College Hospital [42] and District Pakistan [68-71] Kenya in maternity ward kakamega county referral hospital [72]. 
The possible explanations for this possibly due to the pelvic disproportions of these young women make deliveries more difficult and prolonged.

\begin{tabular}{|c|c|c|c|c|c|}
\hline $\begin{array}{l}\text { Characteristi } \\
\text { cs }\end{array}$ & $n=246$ & COR at $95 \% \mathrm{Cl}$ & $\mathbf{P}$ & $\begin{array}{l}\text { AOR at } 95 \% \\
\mathrm{Cl}\end{array}$ & $\mathbf{P}$ \\
\hline \multicolumn{6}{|l|}{ Age of mother } \\
\hline $15-20$ & $\begin{array}{l}40 \\
(16.3 \%)\end{array}$ & $\begin{array}{l}0.03 \\
(0.01-0.09)^{*}\end{array}$ & 0.01 & $\begin{array}{l}0.04 \\
(0.03-0.07)^{\star *}\end{array}$ & $0.04^{*}$ \\
\hline $21-25$ & $\begin{array}{l}92 \\
(37.4 \%)\end{array}$ & $\begin{array}{l}0.01 \\
(0.040-0.071)^{\star}\end{array}$ & 0.03 & $\begin{array}{l}0.02 \\
(0.050-0.091)^{*}\end{array}$ & $0.03^{*}$ \\
\hline $26-30$ & $\begin{array}{l}69 \\
(28.0 \%)\end{array}$ & $\begin{array}{l}1.173 \\
(0.223-6.177)\end{array}$ & 0.851 & $\begin{array}{l}2.283 \\
(0.323-5.265)\end{array}$ & $\begin{array}{l}0.85 \\
1\end{array}$ \\
\hline $31-35$ & $\begin{array}{l}30 \\
(12.2 \%)\end{array}$ & $\begin{array}{l}0.359 \\
(0.067-1.928)\end{array}$ & 0.232 & $\begin{array}{l}0.448 \\
(0.089-3.737)\end{array}$ & $\begin{array}{l}0.23 \\
2\end{array}$ \\
\hline$\geq 36$ & $\begin{array}{l}15 \\
(6.1 \%)\end{array}$ & 1 & & 1 & \\
\hline \multicolumn{6}{|c|}{ Maternal educational status } \\
\hline Illiterate & $\begin{array}{l}136 \\
(55.3)\end{array}$ & $\begin{array}{l}0.05 \\
(0.024-0.037)^{*}\end{array}$ & 0.09 & $\begin{array}{l}0.08 \\
(0.035-0.049)^{*}\end{array}$ & 0.07 \\
\hline Primary & $64(26.0)$ & $\begin{array}{l}0.03 \\
(0.063-0.24)^{*}\end{array}$ & 0.043 & $\begin{array}{l}0.04 \\
(0.023-0.043)^{\star} \\
\text { * }\end{array}$ & $\begin{array}{l}0.03 \\
3\end{array}$ \\
\hline Secondary & $30(12.2)$ & $\begin{array}{l}0.068 \\
(0.905-16.798)\end{array}$ & 3.9 & $\begin{array}{l}0.077 \\
(0.105-13.79)\end{array}$ & 3.9 \\
\hline $\begin{array}{l}\text { Higher } \\
\text { education }\end{array}$ & $16(6.5)$ & 1 & & 1 & \\
\hline \multicolumn{6}{|c|}{ Mode of deliver } \\
\hline SVB & $\begin{array}{l}177 \\
(72.0 \%)\end{array}$ & $\begin{array}{l}1.236 \\
(0.539-2.836)\end{array}$ & 0.617 & $\begin{array}{l}2.325 \\
(0.347-3.747)\end{array}$ & $\begin{array}{l}0.01 \\
7\end{array}$ \\
\hline $\begin{array}{l}\text { Vacuum } \\
\text { delivery }\end{array}$ & $\begin{array}{l}19 \\
(7.7 \%)\end{array}$ & $\begin{array}{l}0.023 \\
(0.071-0.054)^{*}\end{array}$ & 0.04 & $\begin{array}{l}0.042 \\
(0.082-0.043)^{*}\end{array}$ & 0.03 \\
\hline $\begin{array}{l}\text { Forceps } \\
\text { delivery }\end{array}$ & $\begin{array}{l}8 \\
(3.3 \%)\end{array}$ & $\begin{array}{l}0.03 \\
(0.04-0.09)^{*}\end{array}$ & 0.02 & $\begin{array}{l}0.05 \\
(0.06-0.09)^{\star *}\end{array}$ & 0.04 \\
\hline $\mathrm{C} / \mathrm{S}$ & $\begin{array}{l}42 \\
(17.1 \%)\end{array}$ & 1 & & 1 & \\
\hline \multicolumn{6}{|c|}{ Duration of labour } \\
\hline$<18 \mathrm{~h}$ & $\begin{array}{l}206 \\
(83.7 \%)\end{array}$ & $\begin{array}{l}0.05 \\
(0.212-0.9)^{*}\end{array}$ & 0.027 & $\begin{array}{l}0.017 \\
(0.012-0.9)^{*}\end{array}$ & $\begin{array}{l}0.00 \\
7\end{array}$ \\
\hline$\geq 18 \mathrm{~h}$ & $\begin{array}{l}40 \\
(16.3 \%)\end{array}$ & 1 & & 1 & \\
\hline
\end{tabular}

NB: These variables are from the total variables statistical significant while cross tabulation done $(p<0.05)$ (Age of mother, Maternal educational status, Mode of deliver, Gestational age, Duration of labour)

Table 4: Bivariate and multivariate logistic regression model showing predictors of birth asphyxia among babies born from June 1/2014-July 30/2017 at Dilchora referral hospital, Aug 1-Sep 30/2017.

In our study maternal education was one of the factors associated with birth asphyxia. Similar finding were observed in other studies conducted in Tanzania, Mexico City, Southern Nepal and rural district Matiari, Pakistan [33,64-66]. But inconsistent with finding conducted in hospital based study in Bangladesh [42].

So being illiterate was significantly associated with increased risk of birth asphyxia. This finding is consistent with studies conducted in Tanzania, in rural Gana, Rural District Matiari, Pakistan, Sweden, Kenya in maternity ward kakamega county referral hospital $[33,66-68,72]$.

This is may be due to women without formal education might find it difficult to benefit from reproductive health education. Maternal illiteracy is a very broad indicator of poor socio-economic conditions associated with consequent malnutrition, frequent pregnancies and also influences care seeking during antepartum period.

In our study mode of delivery is one of the factor that has significant association with birth asphyxia. Neonate who were delivered by vacuum four times $\mathrm{AOR}=0.042$, 95\% CI (0.082-0.043) and forceps delivery were five times develops birth asphyxia $\mathrm{AOR}=0.05,95 \% \mathrm{CI}$ (0.06-0.09) compared to caesarean section and spontaneous vaginal delivery. In our study 177 (72\%) had spontaneous vaginal delivery (SVD) is higher than study done in Karachi Pakistan [69] and Yaoundé Cameron [70]. Kenya in maternity ward Kakamega county referral hospital [72] (Table 4).

Duration of labour was statistically significant factors in our study. There was significant statistical association observed between mothers who spent less than $18 \mathrm{~h}$ in labour were $98 \%$ less likely to develop birth asphyxia than those spent longer than $18 \mathrm{~h}$ in labour [AOR $(95 \%$ $\mathrm{CI}=0.017(0.012-0.9)]$.

This result is similar with what has been observed in studies done in Cameroon urban health facility in Yaounde and centre of hospital universities of Yaoundé and Kenya in maternity ward kakamega county referral hospital [70-72].

Regarding mode of delivery it showed that babies born with vacuum delivery $[\mathrm{AOR}=0.042(0.082-0.043)]$ four times and forceps delivery [AOR $=0.05(0.06-0.09)]$ five times more likely develops birth asphyxia than those born with $\mathrm{C} / \mathrm{S}$. This is different from study done in Karachi Pakistan [69].

In neonates lives maternal health is often believed as a vital aspect and influences health of neonate, this has positive effect on the prevalence of neonatal asphyxia. The finding of this study showed that $15 \%$ of mothers didn't have follow-up. This is quite less than with the finding obtained in Gusau, Nigeria (66.0\%) [51] had no ANC follow up.

\section{Conclusion}

Based on the finding of the study we have made concluded that significant predictors birth asphyxia was age of mother, educational level, duration of labour, mode of delivery, and duration of labour. There was significant association $(p<0.05)$ between birth asphyxia and associated factors.

\section{Recommendations}

Proper emphasis should be given for neonatal mortality by addressing and providing adequate information because prevalence of birth asphyxia was $25 \%$ in study area. This may increase mortality and morbidity rate of neonates. Indirectly also has effect on quality of care. So that the following recommendation will be forwarded to: 
Health care providers to monitor mothers during labour closely with Partograph to minimize the effects of delayed labour.

Ministry of health and regional health bureau should have to focus on report but also to look the gaps of the health professionals in order to strengthen their knowledge and skill and attitude towards labouring mothers.

A quasi experimental study can be done to assess the knowledge of mothers regarding birth asphyxia.

This study can be elaborated by assessing knowledge, attitude and practice of clinicians about birth asphyxia.

\section{Competing Interests}

We declare that there are no conflicts of interest to disclose.

\section{Acknowledgments}

I would like to express my gratitude to Dr. Catherine Chojenta for her encouragement to publish my paper.

\section{References}

1. World Health Organization (1997) Basic Newborn Resuscitation: A Practical Guide. WHO, Geneva.

2. Ezechukwu CC, Ugochukwu EF, Egbuonu I, Chukwuka JO (2004). Risk factors for neonatal mortality in a regional tertiary hospital in Nigeria. Niger J Clin Pract 7: 50-55.

3. Dilenge, ME, Majnemer A, Shevell MI (2001) Long-Term Developmental Outcome of Asphyxiated Term Neonates. J Child Neurol 16: 781-792.

4. Haider AB, Bhutta ZA (2006). Birth asphyxia in developing countries: Current status and public health implications. Curr Probl Pediatr Adolesc Health Care 36: 178-88.

5. Cunningham FG, Bloom SL, Hauth JC, Rouse DJ, Spong CY, et al. (2010) Williams Obstetrics. 23rd ed. USA: McGraw-Hill.

6. Committee on Fetus and Newborn, American Academy of Pediatrics, and Committee on Obstetric Practice, American.

7. Ruth VJ, Raivio KO (1988) Perinatal brain damage: predictive value of metabolic acidosis and the Apgar score. BMJ 297: 24-27.

8. Keenan WJ, Udaeta E, López M (2009) Delivery and Immediate Neonatal Care. In: Berman S (eds) Pediatric Education in Disasters Manual. American Academy of Pediatrics, Buenos Aires, Argentina 217-237.

9. Ryan S, Gregg T, Patel L (eds) (2003) Core paediatrics: a problem-solving approach. London: Hodder Arnold.

10. FMOH (2007) Intergrated maternal, new born and child health strategies. Abuja, Nigeria.

11. Dalili H, Sheikh M, Kamal A, Hardani, Nili F (2006) The Apgar score. ACOG Committee Opinion No. 333. American Academy of Pediatrics American College of Obstetricians and Gynecologists. Obstet Gynecol 107: 1209-12.

12. Undeshi VA, Ndie EC (2012) Clinical Procedure Guide For Midwife. OJC Academic publishers, Enugu.

13. Volpe JJ (2008) Neurology of the Newborn. Philadelphia: Saunders.

14. American College of Obstetricians and Gynecologists (2006) Umbilical cord blood gas and acid-base analysis ACOG Committee Opinion No. 348. Obstet Gynecol 108: 1319-1322.

15. Rennie JM, Roberton NRC (2002) A manual of neonatal intensive care. Arch Dis Child Fetal Neonatal Ed 89: F279.

16. Parer JT, Ikeda T (2007) A framework for standardized management of intrapartum fetal heart rate patterns. Am J Obstet Gynecol 197: 26.e1-e6.

17. Mir IN, Chalak LF (2014) Serum biomarkers to evaluate the integrity of the neurovascular unit. Early Hum Dev 90: 707-711.
18. Rademakers RP, Knaap VD, Marjo S, Verbeeten, Bernard Jr, et al. (1995) Central Cortico-Subcortical Involvement: A Distinct Pattern of Brain Damage Caused by Perinatal and Postnatal Asphyxia in Term Infants. J Comput Assist Tomogr 19: 256-263.

19. Toft PB (1999) Prenatal and Perinatal Striatal Injury: A Hypothetical Cause of Attention-Deficit-Hyperactivity Disorder? Pediatr Neurol 21: 602-610.

20. Boskabadi H, Navaee Boroujeni A, Mostafavi-Toroghi H, Hosseini G, Ghayour-Mobarhan M, et al. (2014) Prooxidant-antioxidant balance in perinatal asphyxia. Indian J Pediatr 81: 248-253.

21. Lawn JE, Cousens S, Zupan J (2009) Neonatal Survival Steering Team: 4 Million Neonatal Deaths: When? Where? Why? Lancet 365: 891-900.

22. Ferns G, Boskabadi H, Afshari JT, Ghayour-Mobarhan M, Maamouri G, et al. (2010) Association between serum interleukin-6 levels and severity of perinatal asphyxia. Asian Biomed 4: 79-85.

23. Volpe JJ (2001) Perinatal brain injury: from pathogenesis to neuroprotection. Ment Retard Dev Disabil Res Rev 7: 56-64.

24. Low JA, Pickersgill H, Killen H, Derrick EJ (2001) The prediction and prevention of intrapartum fetal asphyxia in term pregnancies. Am J Obstet Gynecol 184: 724-730.

25. Lawn JE, Cousens S, Zupan J (2005) 4 million neonatal deaths: When? Where? Opportunities for Africa's Newborns Why? Lancet 365: 891-900.

26. Lee AC, Kozuki N, Blencowe H, Vos T, Bahalim A, et al. (2013) Intrapartum-related neonatal encephalopathy incidence and impairment at regional and global levels for 2010 with trends from 1990. Pediatr Res 74: 50-72.

27. Save the Children (2001) The state of the world's newborns: a report from saving newborn lives.

28. World Health Organization (2004) The global burden of disease 2004 update.

29. Leviton A, Nelson KB (1992) Problems with Definitions and Classifications of Newborn Encephalopathy. Pediatr Neurol 8: 85-90.

30. World Health Organization (2005) World Health Report. WHO, Geneva.

31. Petten CV (2004) Relationship between Hippocampal Volume and Memory Ability in Healthy Individuals across the Lifespan: Review and Meta-Analysis. Neuropsychologia 42: 1394-1413.

32. Lou HC (1996) Etiology and Pathogenesis of Attention-Deficit Hyperactivity Disorder (ADHD): Significance of Prematurity and Perinatal Hypoxic-Haemodynamic Encephalopathy. Acta Paediatr 85: 1266-1271.

33. Sepeku A, Kohi TW (2011) Treatment outcomes of neonatal asphyxia at a national hospital in dar es salaam, Tanzania. Afr J Nurs Midwifery 13: 43-56.

34. WHO (2000) The World Health Report 2000 Health Systems: Improving performance. Geneva: World Health Organization.

35. United Nations Children's Fund (2004) The state of the world's children 2004.

36. Lopez AD, Mathers CD, Ezzati M, Jamison DT, Murray CJ (2006) Global and Regional Burden of Disease and Risk Factors, 2001: Systematic Analysis of Population Health Data. Lancet 367: 1747-1757.

37. Lopez AD, Mathers CD (2006) Measuring the Global Burden of Disease and Epidemiological Transitions: 2002-2030. Ann Trop Med Parasitol 100: 481-499.

38. Federal democratic republic of Ethiopia Ministry of Health, BEmONCLRP (2013) Best practice in maternal and newborn care Maternal Death Surveillance and Response.

39. Ferns G, Boskabadi H, Afshari JT, Ghayour-Mobarhan M, Maamouri G, et al. (2010) Association between serum interleukin-6 levels and severity of perinatal asphyxia. Asian Biomed 4: 79-85.

40. Thornberg E, Thiringer K, Odeback A, Milsom I (1995) Birth asphyxia: incidence, clinical course and outcome in a Swedish population. Acta Paediatr 84: 927-932.

41. Antonucci R, Porcella A, Pilloni MD (2014) Perinatal asphyxia in the term newborn. J Pediatr Neonat Individual Med 3: e030269. 
Citation: Ibrahim NA, Muhye A, Abdulie S (2017) Prevalence of Birth Asphyxia and Associated Factors among Neonates Delivered in Dilchora Referral Hospital, in Dire Dawa, Eastern Ethiopia. Clinics Mother Child Health 14: 279. doi:10.4172/2090-7214.1000279

Page 7 of 7

42. Shireen N, Nahar N, Mollah AH (2009) Risk Factors and Short-Term Outcome of Birth Asphyxiated Babies in Dhaka Medical College Hospital. Bangladesh J Child Health 33: 83-89.

43. Black RE, Morris SS, Bryce J (2003) Where and why are 10 million children dying every year? Lancet 361: 2226-2234.

44. Lawn J, Mongi P, Cousens S (2011) Africa's newborns-counting them and making them count. Opportunities for Africa's Newborns.

45. Lawn JE, Blencowe H, Oza S, You D, Lee AC, et al. (2014) Every Newborn: Progress, Priorities, and Potential beyond Survival. Lancet 384: 189-205.

46. Lawn JE, Manandar A, Haws RA, Darmstadt GL (2007) Reducing one million child deaths from birth asphyxia-a policy and programme gaps and priorities based on an international survey. Health Res Policy Syst 5: 4 .

47. Central Statistical Agency (CSA) and ICF (2016) Ethiopia Demographic and Health Survey 2016. Addis Ababa, Ethiopia, and Rockville, Maryland, USA: CSA and ICF.

48. WHO (2013) Levels \& Trends in Child Mortality.

49. Committing to Child Survival: A Promise Renewed 2013.

50. Black RE, Cousens S, Johnson HL, Lawn JE, Rudan I, et al. (2010) Global, regional, and national causes of child mortality in 2008: a systematic analysis. Lancet 375: 1969-1987.

51. Ilah BG, Aminu MS, Musa A, Adelakun MB, Adeniji AO, et al.(2015) Prevalence and Risk Factors for Perinatal Asphyxia as Seen at a Specialist Hospital in Gusau, Nigeria Sub-Saharan Afr J Med.

52. Berglund S, Grunewald C, Pettersson H, Cnattingius S (2010) Risk factors for asphyxia associated with substandard care during labor. Acta Obstet Gynecol Scand 89: 39-48.

53. Parer JT, King T, Flanders S, Fox M, Kilpatrick SJ (2006) Fetal acidemia and electronic fetal heart rate patterns: is there evidence of an association? J Matern Fetal Neonatal Med 19: 289-294.

54. American Heart Association (2006) Guidelines for cardiopulmonary resuscitation (CPR) and emergency cardiovascular care (ECC) of pediatric and neonatal Patients: pediatric basic life support. Pediatr 117: e989-e1004.

55. Kali GT, Martinez-Biarge M, Van Zyl J, Smith J, Rutherford M (2015) Management of therapeutic hypothermia for neonatal hypoxic ischaemic encephalopathy in a tertiary centre in South Africa. Arch Dis Child Fetal Neonatal Ed 100: F519-F523.

56. Dilenge ME, Majnemer A, Shevell MI (2001) Long-term developmental outcomes of asphyxiated term neonates. J Child Neurol 16: 781-792.

57. Boskabadi H, Ashrafzadeh F, Doosti H, Zakerihamidi M (2015) Assessment of Risk Factors and Prognosis in Asphyxiated Infants. Iran J Pediatr 25: e2006.
58. Chikuse B, Chirwa E, Maluwa A, Malata A, Odland J (2012) Midwives' adherence to guidelines on the management of birth asphyxia in Malawi. Open J Nurs 2: 351-357.

59. de Graft-Johnson J, Vesel L, Rosen HE, Rawlins B, Abwao S, et al. (2017) Assessment of quality of newborn care immediately after birth in health facilities across six sub-Saharan African countries BMJ Open 7: e014680.

60. Mengesha HG, Sahle BW (2017) Cause of neonatal deaths in Northern Ethiopia: BMC Public Health 17: 62.

61. Aragaw YA (2016) Perinatal Mortality and associated Factor in Jimma University Specialized Hospital, South West Ethiopia Gynecol Obstet 6: 11.

62. Malhotra S, Zodpey SP, Vidyasagaran AL, Sharma K, Raj SS, et al. (2014) Assessment of Essential Newborn Care Services in Secondary-level Facilities from Two Districts of India. J Health Popul Nutr 32: 130-141.

63. Abbasalizadeh F, Abbasalizadeh S, Pouraliakbar S, Bastani P (2015) Correlation between Nonreassuring Patterns in Fetal Cardiotocography and Birth Asphyxia. Int J Womens Health Reproduction Sci 3: 151-154.

64. Lee AC, Mullany LC, Tielsch JM, Katz J, Khatry SK, et al. (2008) Risk Factors for Neonatal Mortality Due to Birth Asphyxia in Southern Nepal: A Prospective, Community-Based Cohort Study. Pediatr 121: e1381e1390.

65. Cruz-Anguiano V, Talavera JO, Vázquez L, Antonio A, Castellanos A, et al. (2004) The Importance of Quality of Care in Perinatal Mortality: A Case-Control Study in Chiapas, Mexico. Med Res Arch 35: 554-562.

66. Tabassum F, Rizvi A, Ariff S, Sajid Soofi, Bhutta ZA (2014) Risk Factors Associated with Birth Asphyxia in Rural District Matiari, Pakistan. Int J Clin Med 5: 1430-1441.

67. Bouwhuis SA, Davis MD (2004) Contribution of Sexually Transmitted Diseases and Socioeconomic Factors to Perinatal Mortality in Rural Ghana. Int J Dermatol 43: 27-30.

68. Stephansson O, Dickman PW, Johansson AL, Cnattingius S (2001) The Influence of Socioeconomic Status on Stillbirth Risk in Sweden. Int J Epidemiol 30: 1296-1301.

69. Aslam MH, Saleem S, Afzal R, Iqbal U, Saleem SM, et al. (2014) Risk factors of birth asphyxia. Ital J Pediatr 40: 94.

70. Chiabi A, Nguefack S, Mah E, Nodem S, Mbuagbaw L, et al. (2013) Risk Factors for Birth Asphyxia in an Urban Health Facility in Yaounde Cameroon. Iran J Child Neurol 7: 46-54.

71. Monebenimp F, Tietche F, Eteki N (2005) Asphyxie néonatale au centre hospitalier universitaire de Yaoundé. CMCH 2: 335-338.

72. Kibai, Kiptui E (2017) Perinatal factors associated with birth asphyxia among neonates in maternity ward kakamega county refferal hospital, kenya. MMUST Digital Repository. 